EDITORIAL EXPRESSION OF CONCERN

\title{
Editorial Expression of Concern: Dynamic in vivo interactions among Myc network members
}

Xiao-ying Yin, Melanie F. Landay, Weiping Han, Edwin S. Levitan, Simon C. Watkins, Richard M. Levenson, Daniel L. Farkas and Edward V. Prochownik

(c) The Author(s), under exclusive licence to Springer Nature Limited 2021

Oncogene (2021) 40:6308; https://doi.org/10.1038/s41388-021-01953-9

The Editors-in-Chief would like to alert readers that concerns have been raised regarding this article [1].

It appears that Figure 7 contains multiple duplications. However, it does not affect the main conclusions of the article as to the subcellular location, appearance and interactions of the various proteins analysed.

Richard M Levenson, Daniel L Farkas, Edward V Prochownik and Edwin S Levitan agree to this Editorial Expression of Concern. Xiao-ying Yin, Melanie F Landay, Weiping Han and Simon C Watkins have not responded to any correspondence from the publisher about this Editorial Expression of Concern.
The original article can be found online at https://doi.org/10.1038/ sj.onc. 1204606

\section{REFERENCE}

1. Yin X, Landay MF, Han W, Levitan ES, Watkins SC, Levenson RM, et al. Dynamic in vivo interactions among Myc network members. Oncogene. 2001;20:4650-64. https://doi.org/10.1038/sj.onc.1204606

\section{ADDITIONAL INFORMATION}

Correspondence and requests for materials should be addressed to E.V.P.

Reprints and permission information is available at http://www.nature.com/ reprints 